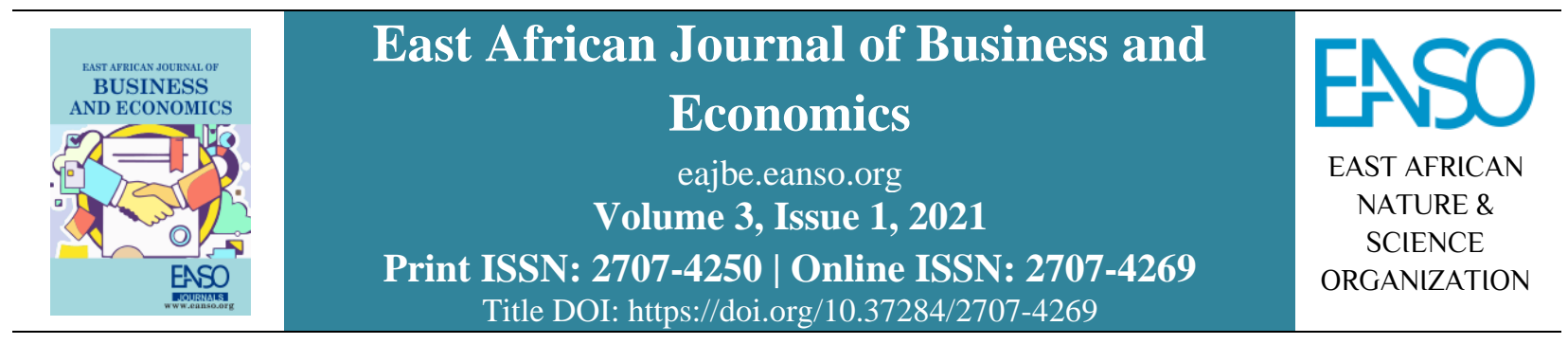

Original Article

\title{
Digital Credit in Kenya: A Survey of Costs, Uses and Borrowers Considerations in Relation to Loan Uptake.
}

\author{
Charles Guandaru Kamau ${ }^{1}$ \\ ${ }^{1}$ Technical University of Mombasa, P. O. Box 90420 Mombasa, Kenya . \\ * ORCID: https://orcid.org/0000-0002-8085-0421; Correspondence email: guandaruman@ yahoo.co.uk.
}

Article DOI: https://doi.org/10.37284/eajbe.3.1.402

\section{Date Published: ABSTRACT}

08 September 2021 Digital credit involves use of mobile telephone devices and online platforms to secure short term credit. Digital credit has been on a steady rising trend in

Keywords: Kenya since 2012. Availability of credit by households especially the lowincome persons have been of great concern for many years. Digital credit has

Digital Credit, come in handy to address this concern to a great extent. The main aim of this

Cost Of Finance, study was to analyse the cost of digital credit, the uses to which the borrowers apply the digital loans and the factors that they consider before applying for the Uses Of Digital Loans, digital loan in Kenya. The data collection methods used are analysis of

Borrower's secondary data and online surveys. The study analysed the data using paired Considerations, sample $\mathrm{t}$ tests and regression analysis methods. The study observed that there Loan Uptake. is no significant difference between the cost of digital loans and the banks' lending rate in Kenya. The findings of this study employment status and loan application have a statistically significant effect on the level of loan uptake. Digital credit users age and loan considerations did not have statistically significant effect on the loan uptake.

\section{APA CITATION}

Kamau, C. G. (2021). Digital Credit in Kenya: A Survey of Costs, Uses and Borrowers Considerations in Relation to Loan Uptake. East African Journal of Business and Economics, 3(1), 164-172. https://doi.org/10.37284/eajbe.3.1.402

\section{CHICAGO CITATION}

Kamau, Charles Guandaru. 2021. "Digital Credit in Kenya: A Survey of Costs, Uses and Borrowers Considerations in Relation to Loan Uptake". East African Journal of Business and Economics 3 (1), 164-172. https://doi.org/10.37284/eajbe.3.1.402.

\section{HARVARD CITATION}

Kamau, C. G. (2021) "Digital Credit in Kenya: A Survey of Costs, Uses and Borrowers Considerations in Relation to Loan Uptake”, East African Journal of Business and Economics, 3(1), pp. 164-172. doi: 10.37284/eajbe.3.1. 402.

\section{IEEE CITATION}

C. G. Kamau, "Digital Credit in Kenya: A Survey of Costs, Uses and Borrowers Considerations in Relation to Loan Uptake", EAJBE, vol. 3, no. 1, pp. 164-172, Sep. 2021.

164 | This work is licensed under a Creative Commons Attribution 4.0 International License. 


\section{MLA CITATION}

Kamau, Charles Guandaru. "Digital Credit in Kenya: A Survey of Costs, Uses and Borrowers Considerations in Relation to Loan Uptake". East African Journal of Business and Economics, Vol. 3, no. 1, Sep. 2021, pp. 164-172, doi:10.37284/eajbe.3.1.402

\section{INTRODUCTION}

Digital credit refers to the financial advances accessed through a digital platform available online or by use of mobile devices. Previously, many households have been reported to have challenges in accessing credit especially in developing countries. This was perhaps because the cost of physically providing small loans to low income and remote populations is costly. Digitization of money and related transactions in developing countries have led to the change of landscape on how households access credit. "Mobile money enables inexpensive financial transfers, and mobile phones capture behaviour that can predict repayment when mined with machine learning" (Björkegren \& Grissen, 2018). Digital credit has led to increases in borrowing opportunities, especially for individuals who are less likely to have credit access in the conventional credit markets. On the other hand, digital credit responsible for ninety percent of all black listings due to high default rates (Johnen, Parlasca, \& Mußhoff, 2021). Mobile money systems allow monetary transactions to take place from mobile devices which are currently available to most people including the low-income cadre. It is often referred to as "a bank in one's pocket,". These digital technologies have played a key role in reshaping rural markets for savings, credit, and insurance services in developing countries (Benami \& Carter, 2021).

One of the pioneer innovations on digital credit in Kenya is Safaricom's MShwari loans which was launched in November 2012. Ever since, other large banks such as Kenya Commercial Bank, Equity Bank, and Co-operative Bank as well as a growing number of FinTechs and non-bank institutions started offering digital credit. These digital credit providers have since established diverse models used to score and distribute loans to interested customers (Totolo, 2018). Digital credit has enhanced the level of financial inclusion for lowincome earners in developing countries. Digital credit is becoming attractive due to its remote nature, instant accessibility and automated identity protection (Momanyi, 2021).

The amount of credit requested from digital lenders has an effect on credit usage. Likewise, the level of credit availability, probably due to increased number of Fintech agents, greatly influences the credit usage among the SMEs in Kenya (Abbott, 2020). Online digital and mobile banking have played a key role in improving the accessibility of credit facilities to households and SMEs. These digital loans provide easy access to short term finance at reasonable costs (Kamau, 2021). One of the key risks that the credit providers are keen to manage, is the loan default risk. Most companies strive to ensure that their loans are sufficiently covered either through insurance or other collateral securities. The firms that carry out loan reviews regularly manages to reduce loan defaults to some extent (Nthiga \& Simiyu, 2021).

A study by Wathome (2020) established that, more male youth were engaging in digital borrowing as compared to female and that digital credit use was rampant among youth who had attained an advanced level of education. He also found that bank-owned digital credit services which were directly linked to their mobile phone service were quite popular (Wathome, 2020). There is a positive weak relationship between digital credit and education levels of low-income borrowers in Kenya. Additionally, there is a significant relationship between digital credit and standard of living as well as the health of low-income borrowers in Kenya (Babu, 2020). 
Wamalwa, Rugiri, and Lauler (2019) observed that financial literacy leads to reduced utilization of digital credit. The study further revealed that persons using digital credit are more likely to dispose their household assets in order to service their loan. Digital credit borrowers have a higher number of loans and lower income compared to those using conventional credit or not using credit. The researchers suggest that use of conventional credit is preferred to digital credit.

This study explored the issues of cost of digital credit as compared to the cost of convectional credit. The study also analysed the use of digital credit as well as the factors that the borrowers consider before securing a digital loan. The study analyses the digital credit users across the various ages and nature of employment or source of livelihood.

\section{METHODOLOGY}

The study employed both primary and secondary data in its analysis. Primary data was collected using

Table 1: t-Test: Paired Two Sample for Means an online survey questionnaire where $71.1 \%$ of the respondents were male while the rest were female. Secondary data was collected from the readily available market information. The main loans of focus included: Branch, Equitel Eazzy Plus Loan, Equitel Eazzy Loan, Jumo-Kopa Cash, KCB-MPesa, Kopa Chapaa, M-Shwari, Okoa Stima, Pesa na Pesa, Pesa Pata, Pesa Zetu, Saida, Tala, and Zindisha. This list was adapted from Kaffenberger and Chege (2016).

\section{FINDINGS}

\section{Cost of Digital Credit}

The study conducted a paired sample t test of the effective annual interest rate offered by 14 different types of digital credit brands available in the market as compared to the average banks' lending rate. The results are as shown in Table 1.

\begin{tabular}{lll}
\hline & Digital Credit Rates & Banks' Lending Rate \\
\hline Mean & 0.565 & 0.166 \\
Variance & 2.606 & $8.3 \mathrm{E}-34$ \\
t Stat & 0.926 & \\
$\mathrm{P}(\mathrm{T}<=\mathrm{t})$ one-tail & 0.186 & \\
$\mathrm{t}$ Critical one-tail & 1.7709 & \\
$\mathrm{P}(\mathrm{T}<=\mathrm{t})$ two-tail & 0.3715 & \\
$\mathrm{t}$ Critical two-tail & 2.1604 & \\
\hline
\end{tabular}

The results in Table 1 indicates that the t Stat (0.926) is less than the critical $t$ for both one tail (1.7709) and two tail (2.1604), therefore null hypothesis is accepted. This implies that the mean of digital credit lending rate is not significantly different from the banks' lending rate. The cost of digital credit is higher than the banks' lending rate, but the difference is not significantly big for the borrowers to change their preferences. This may have been the case due to forces of demand and supply, since both conventional and digital lenders target the same individual lenders. They are likely to be scrambling for the same market.

\section{Uses and Users of Digital Credit}

Several questions were asked using an online questionnaire under this subject.

\section{Level of Digital Borrowing}

The respondents were required to state whether they have ever borrowed digitally. The results indicated 
that $83.5 \%$ have accessed digital credit while $16.5 \%$ have never borrowed digitally. These results do not necessarily imply that the loan uptake is at $83.5 \%$. The reason being that all the persons who responded to the questionnaire had access to a phone or laptop since the survey was online. However, we may conclude that more than $80 \%$ of the people who have access to digital devises have actually applied for a digital loan.

\section{Figure 1: Borrowing by age}

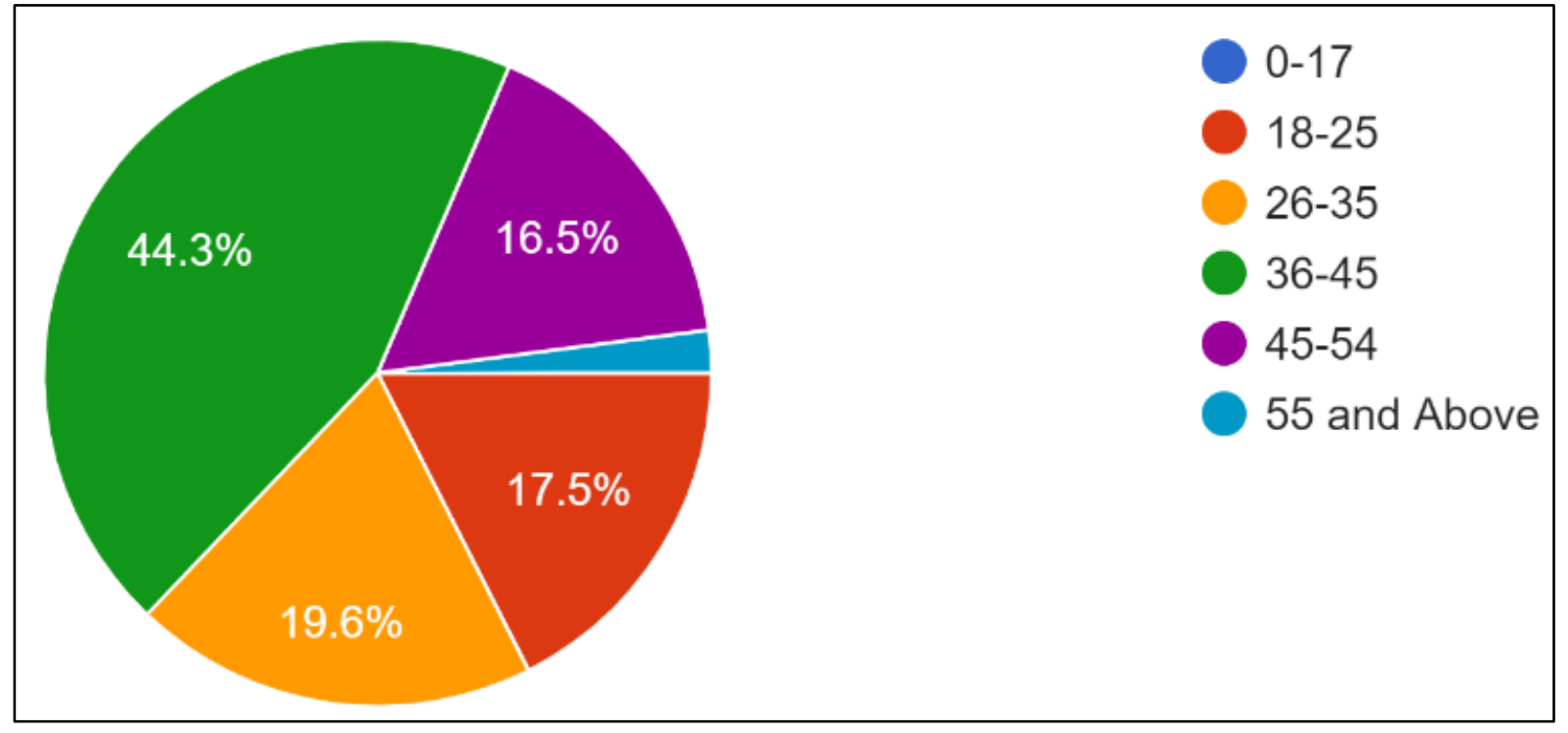

In Kenya, age of 35 is considered the cut point between youth and non-youth population. This therefore implies that almost two-thirds of the digital credit users were beyond the youthful age. This could be due to the fact that these individuals have more societal responsibilities than the youth. Another reason would be the fact that most people in this age bracket have already secured a stable employment or self-employment, hence they can easily access any form of credit including digital credit.

\section{Digital Borrowing by Age}

The respondents were required to state their age. The results showed that out of the respondents who have ever taken a digital loan, about $27 \%$ were youth and $63 \%$ were beyond the age of 35 years, out of whom $2.1 \%$ were above 55 years old. The specific results are as shown in Figure 1.

\section{Popular Digital Credit Brands}

The respondents were required to select a number of digital credit brands that they have used. The results showed that M-Shwari loans were the most popular (76.7\%), followed by KCB Mpesa (48.8\%), then followed by Tala (36\%). The next popular loans were Equitel Eazzy loans (32.5\%) and Branch (23.3\%) respectively.

Majority on the respondents applied for more than one loans. A Venn diagram was constructed using the percentage of the loans taken, with a focus on the three most popular loans. The results were as shown in Figure 2. 
Figure 2: Digital credit Brands popularity

OTHER COMBINATIONS

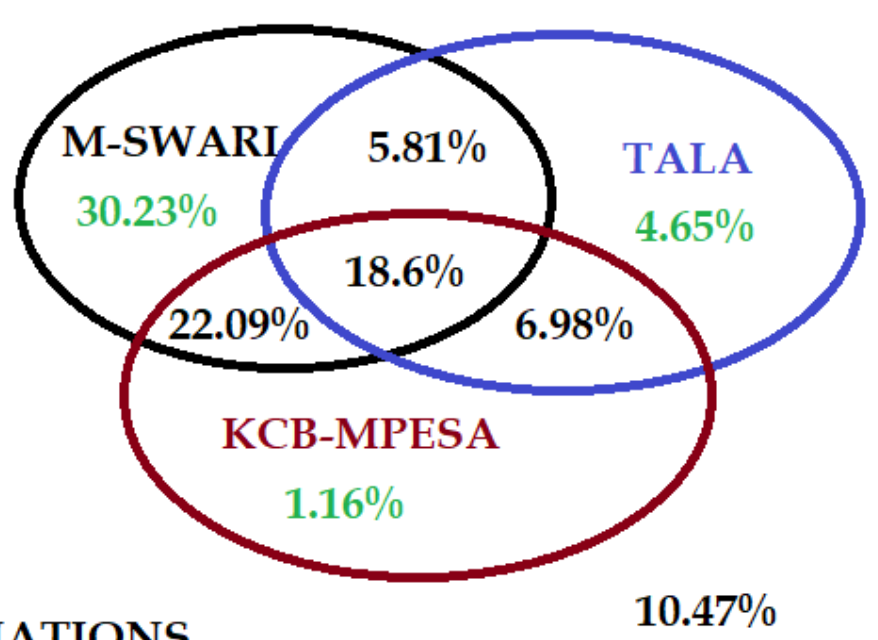

The results showed that the three most popular loans accounted for 89.53 of the total loans taken by the respondents. The other combinations outside the popular loans accounted for $10.47 \%$. The reasons why Mshwari is the leading digital credit brand could be the fact that it was the first loan to be rolled out via mobile phones in Kenya. This means that it has been around for the longest period of time. Secondly it is being offered by the leading mobile phone service provider in Kenya which is Safaricom Kenya limited.

\section{Digital Credit Borrowers' Employment Status}

On the employment status of digital loan borrowers, the respondents were required to state their age group. The results were as shown in Figure 3.

\section{Figure 3: Employment status}

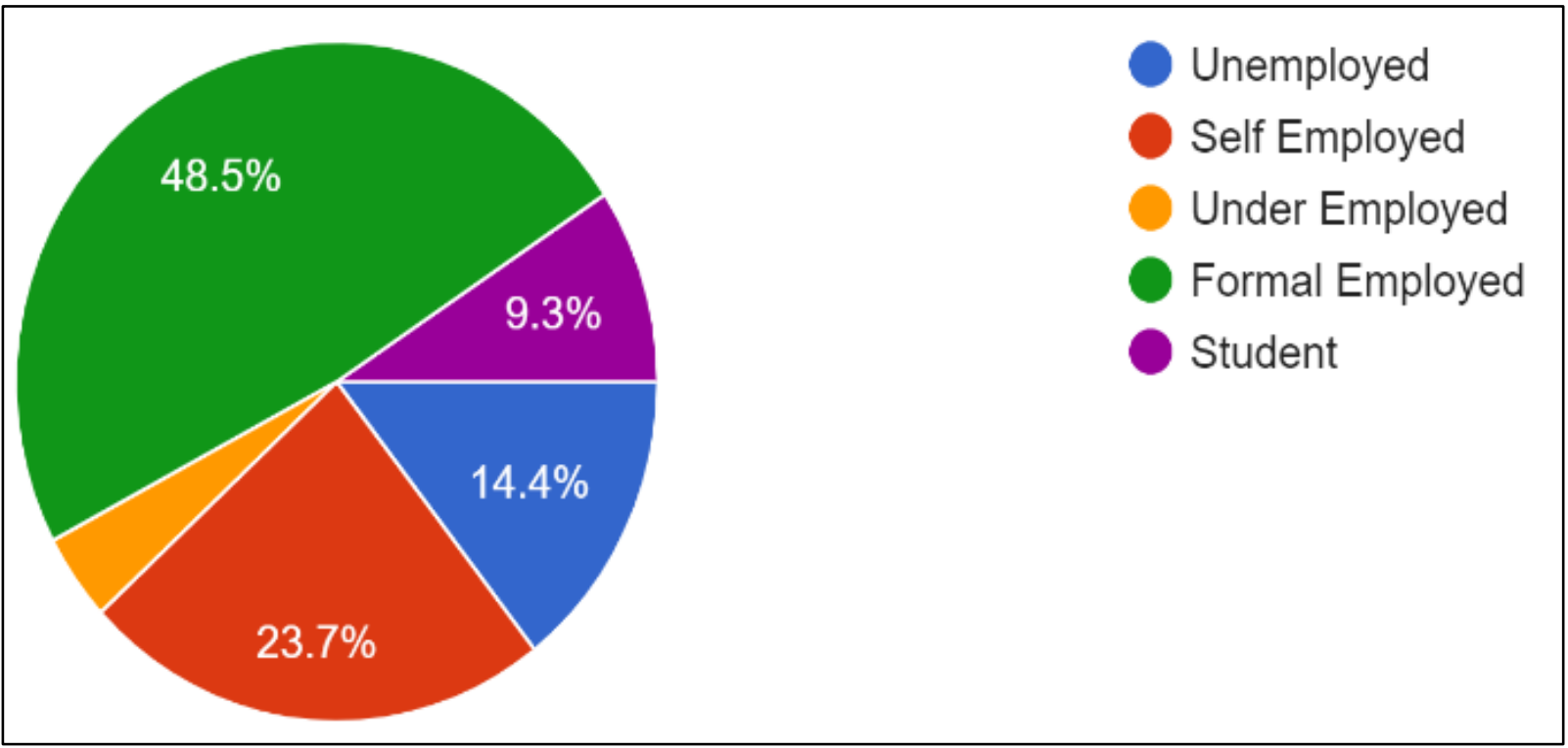

168 This work is licensed under a Creative Commons Attribution 4.0 International License 
The results indicated that majority of the digital loan users were in formal employment $(48.5 \%)$, followed by self-employed individuals $(23.7 \%)$. Unemployed people and students also account for $14.4 \%$ and $9.3 \%$ respectively. Only $4.1 \%$ of the underemployed people take up the digital loans. The results clearly shows that most of the digital credit users had some source of livelihood. No minor was reported to have applied for digital credit, perhaps because of the regulations and that they do not have direct access to the digital devices. Getting direct access to the devise requires one to have an identification card, which they do not have.

\section{Digital Credit Applications}

The other aspect that was being assessed by the study was on the reasons why the respondents took the digital loans. The needs that necessitated the application of the digital loans.

\section{Figure 4: Digital Loan applications/uses}

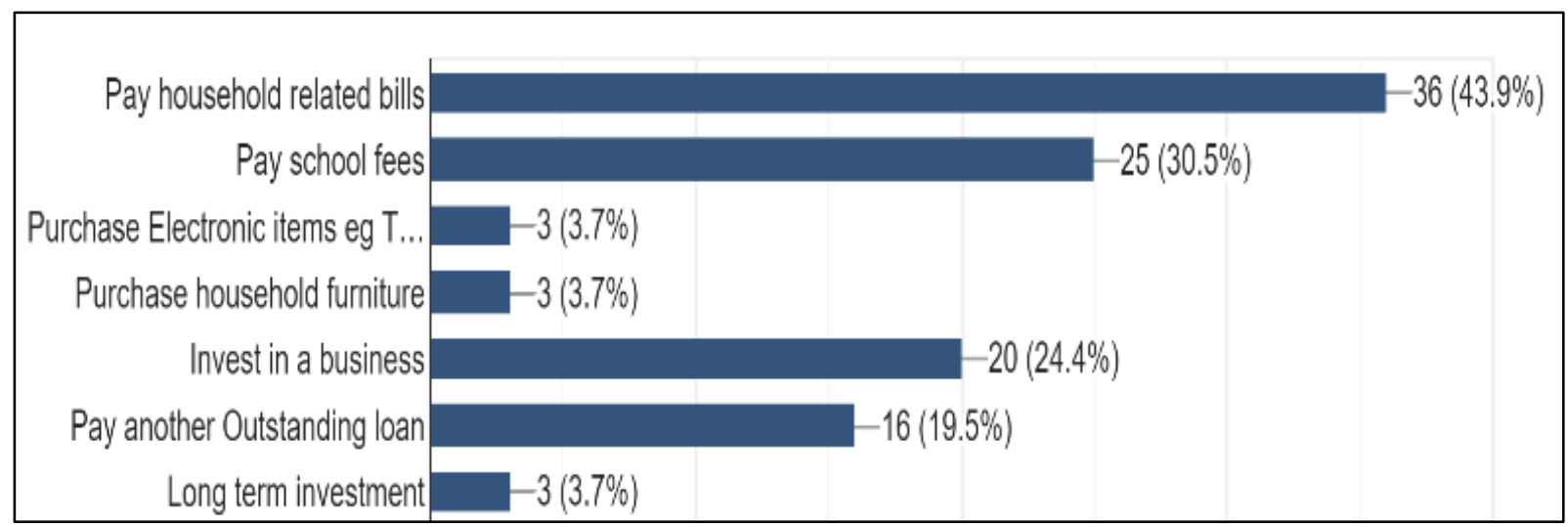

The results show that about half of the respondents took a digital loan for more than one reasons. The leading reason for taking the digital loan was payment of household related bills (43.9\%), followed by payment of school fees (30.5\%). The third popular reason for taking digital loans is to invest in a business (28.1\%) followed by payment of an outstanding loan (19.5\%). Other reasons which were less frequent included: Purchase of furniture and household equipment (7.4\%), betting and having fun at $1.2 \%$ each.

The results imply that a majority of the digital credit users, applied for credit for the purposes of meeting short term immediate household related needs. Most of these uses were not business oriented, meaning that no return was expected from them. This therefore implies that the loan repayments funds were sourced from the employment or selfemployment income.

\section{Factors Considered by Digital Credit Borrowers}

The respondents were required to indicate the factors that they consider before applying for a digital loan. Most of the respondents considered more than one factors. The results were as shown in Figure 5. 
Figure 5: Borrowers Considerations

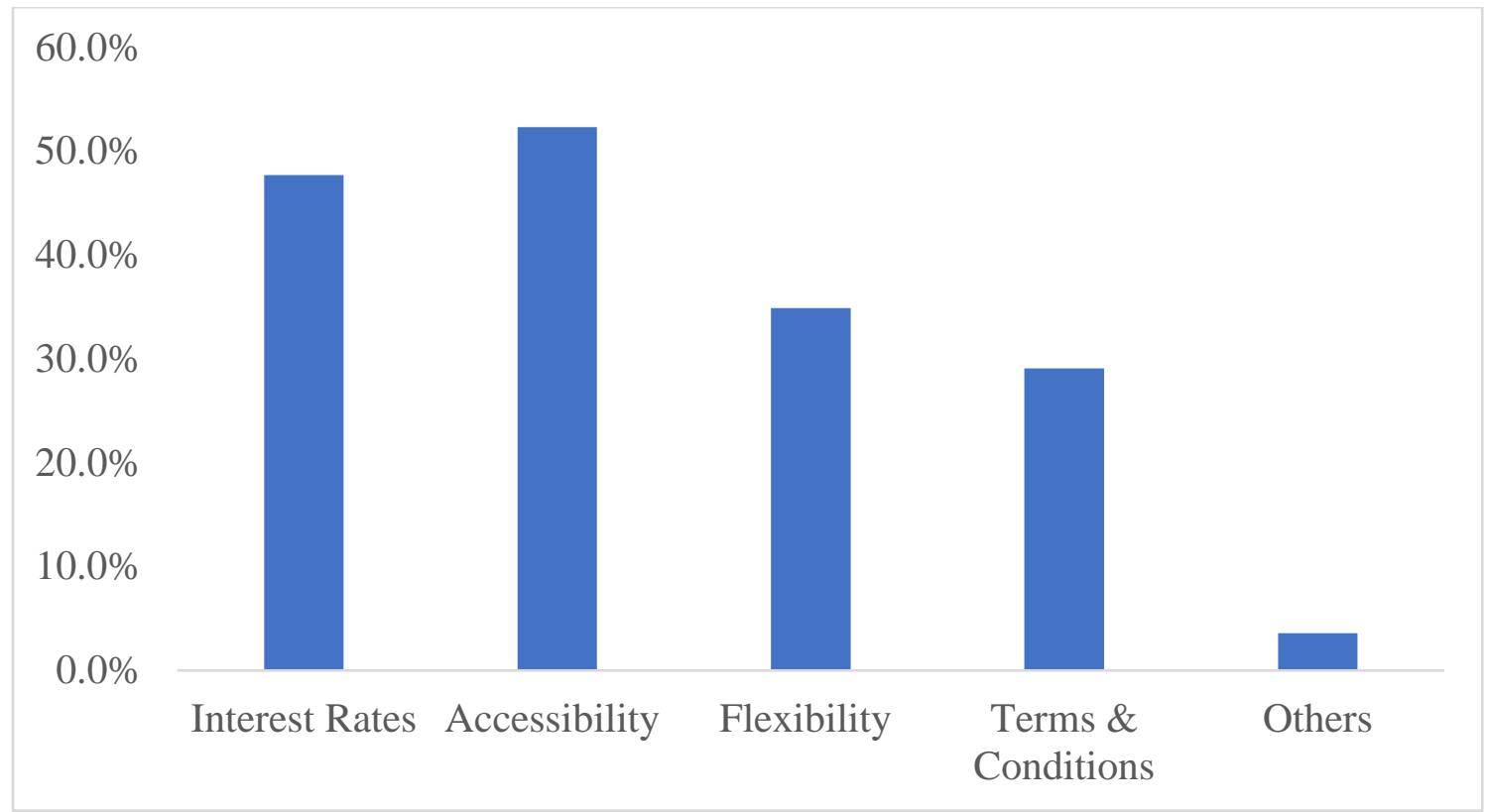

The results showed that accessibility to the digital credit was the leading consideration at 52.3\%, followed by interest rates $(47.7 \%)$. Loan repayment flexibility and terms and conditions were also highly considered at $34.9 \%$ and $29.1 \%$ respectively. Other considerations which accounted for $3.6 \%$ included: emergencies, loan tenure and loan users' personal situations.

This implies that a majority of the digital loan users go for them mainly because of their availability and accessibility, as compared to the rest of the factors. Interest rates is therefore a secondary consideration for them, whereas it should be the primary consideration from the investors point of view. The reason interest rates are not a primary consideration could be that, most of the loan users do not invest the funds, therefore they are not keen on the costs since there is no expected profit.

\section{Regression Analysis}

The data collected was cleaned and coded in line with the study variables. The dependent variable was the level of loan uptake (as observed using the number of loan brands taken), while the independent variables were: digital loan users age, users employment status, loan application and consideration factors.

The ANOVA table (Table 2), which reports how well the regression equation fits the data. The results in Table 2 indicated that the regression model predicts the dependent variable significantly well. The "Sig." column indicates the statistical significance of the regression model that was run. Here, $\mathrm{p}<0.008$, which is less than 0.05 , which means that, the overall regression model statistically significantly predicts the outcome variable (i.e., it is a good fit for the data).

\section{Table 2: ANOVA}

\begin{tabular}{llllll}
\hline & $\boldsymbol{d} \boldsymbol{f}$ & $\boldsymbol{S S}$ & $\boldsymbol{M S}$ & $\boldsymbol{F}$ & Significance $\boldsymbol{F}$ \\
\hline Regression & 4 & 26.942 & 6.735 & 3.709 & 0.008 \\
Residual & 92 & 167.058 & 1.816 & & \\
Total & 96 & 194.000 & & & \\
\hline
\end{tabular}


The regression analysis was carried out on the effect of digital loan users age, users' employment status, loan application and consideration factors on the level of loan uptake. The results were as shown in Table 3.

Table 3: Regression Analysis

\begin{tabular}{lllll}
\hline & Coefficients & Std Err & t Stat & P-value \\
\hline Intercept & 0.209 & 0.727 & 0.288 & 0.774 \\
Age & 0.005 & 0.016 & 0.329 & 0.743 \\
Employment status & 0.286 & 0.149 & 1.920 & 0.048 \\
Loan application & 0.481 & 0.160 & 3.003 & 0.003 \\
Consideration & -0.074 & 0.133 & -0.553 & 0.581 \\
\hline
\end{tabular}

$Y=$ the level of digital loan uptake

The regression results indicates that, the most significant factor that influences loan uptake was loan application followed by employment status. These two variables had a significant influence on the loan uptake since their corresponding P-values were less than 0.05 . On the other hand, digital credit users age and loan considerations had no statistically significant influence on loan uptake since the $\mathrm{P}$ values were more than 0.05 .

The results imply that loan users with more stable sources of income and livelihood are more likely to have a higher loan uptake as compared with the unemployed and under employed users. Additionally, the loan users who have more needs, are likely to engage digital credit more than the loan users with less needs. That is, there is high correlation between loan uptake and loan application or the uses to which a loan user employs. The results further suggests that there was no enough statistical evidence that age of the loan user and loan considerations by the user had influence on the loan uptake. However, it can be observed that the relationship between loan uptake and loan consideration is inverse in nature. This can be interpreted to mean that a number of users are likely to take up digital loans as a result of unnecessary considerations.

\section{CONCLUSIONS AND RECOMMENDATIONS}

Availability of credit by households especially the low-income persons have been of great concern for many years. Digital credit has come in handy to address this concern to a great extent. However, a number of issues need to be assessed so as to avoid any risks that may arise as a result of increased accessibility to credit. This study has addressed a few of such issues as explained in the previous chapters.

This study makes a number of conclusions from the data analysed. First, there is no significant difference between the cost of digital credit and cost of conventional loans as captured by the banks' lending rate. Secondly, most of the people beyond the age of youth (35 years) are more likely to engage in digital borrowing. The study also concludes that M-Shwari, KCB-Mpesa and Tala loans are the leading digital credit brands in Kenya in that order. The three are mobile telephone-based loans. Another conclusion is that a significant majority of digital loan users employ the loans to uses other than for investment. Quite a number of users take up digital loans to repay previous loans, which is not advisable from an investments point of view. Accessibility of digital credit is a major motivator for people to take up such loans, with interest rates being a secondary consideration.

The study further concludes that employment status and loan application have a statistically significant effect on the level of loan uptake. Digital credit users age and loan considerations did not have 
statistically significant effect on the loan uptake. However, the two factors can no be wished away.

One of the limitations of this study was that, the respondents' demographics could not be confirmed as a representation of the actual situation. This is because, only people with access to internet were able to respond to this survey. The situation of the users with rare access to internet is not captured by this study. This becomes one of the recommendations. That, a study can be conducted on uptake of digital credit among the users with less frequent access to internet in Kenya. The study further recommends that, further researches can be conducted on the issues of default risk among the digital credit users, especially among the unemployed and youthful people.

\section{REFERENCES}

Abbott, B. (2020). Financial technology and credit usage among small and medium enterprises in Kisumu central business district, Kenya. University of Nairobi.

Babu, N. (2020). Effect of Digital Credit on Poverty Reduction among Low Income Borrowers in Kenya: A Case of Major Digital Credit Providers in Kenya. United States International University-Africa.

Benami, E., \& Carter, M. R. (2021). Can digital technologies reshape rural microfinance? Implications for savings, credit, \& insurance. Applied Economic Perspectives and Policy, 2021, 1-25.

Björkegren, D., \& Grissen, D. (2018). The potential of digital credit to bank the poor. In AEA Papers and Proceedings (Vol. 108, pp. 68-71).

Johnen, C., Parlasca, M., \& Mußhoff, O. (2021). Promises and pitfalls of digital credit: Empirical evidence from Kenya. Plos one, 6(7), e0255215.

Kaffenberger, M., \& Chege, P. (2016, October 3). Digital Credit in Kenya: Time for Celebration or
Concern? Consultative Group to Assist the Poor (CGAP). https://www.cgap.org/blog/digitalcredit-kenya-time-celebration-or-concern

Kamau, C. G. (2021). Availability of Finance, Finance Costs, and Business Success in Kenya: Focus on the Small and Micro Enterprises. EPRA International Journal of Economics, Business and Management Studies, 8(8), 26-30.

Momanyi, C. (2021). Digital credit for economic development, a case of ISBI's model of lending to micro-entrepreneurs in the Eastland's of Nairobi. Strathmore University.

Nthiga, A. K., \& Simiyu, E. (2021). Credit Management Practices and Lending Decision by Digital Financial Firms in Kenya. Journal of Finance and Accounting, 5(1), 49-69.

Totolo, E. (2018). The digital credit revolution in Kenya: an assessment of market demand, 5 years on. Financial Service Deepening Kenya.

Wamalwa, P., Rugiri, I., \& Lauler, J. (2019). Digital Credit, Financial Literacy and Household Indebtedness. Kenya Bankers Association.

Wathome, F. N. (2020). Effects of Digital Credit on Financial Inclusion of the Youth in Kenya: A Survey of Kangemi, Nairobi County. United States International University-Africa. 